\title{
Basic Sciences: An Alternative career?
}

\section{Khatri R}

Department of Clinical Biochemsitry

College of Medical Sciences Teaching Hospital

Bharatpur, Chitwan

\begin{abstract}
Career selection is a crucial and a complex process which is also true in the medical profession as well. In the context of our country, due to the limited opportunity and proper guidance, migration of medical graduates to foreign countries is increasing. Though, clinical subjects have a huge attraction, basic science field has failed to impress our medical graduates. In current scenario, basic science field seems to be a dumping site for the incompetent as the candidates who have failed trying their luck elsewhere stumble upon basic science careers though it is not true for all. Moreover, a very few medical graduates are interested in developing their career as a basic scientist. Therefore, to motivate today's young medical graduates, there is a need of a good mentor along with a proper career guidance which can help them to understand the basic science field as an alternative career.
\end{abstract}

Corresponding Author

Roshan Khatri

Department of Clinical Biochemsitry

College of Medical Sciences Teaching Hospital

Bharatpur, Chitwan

E-mail: roshankhatri@gmail.com

Citation

\section{KEY WORDS}

Basic science, career, clinical science

Khatri R. Basic Sciences: An Alternative career?. Kathmandu Univ Med J 2013;41(1):78-80.

\section{CAREER DILEMMA}

Choosing a career is a crucial, a complex and a compound process. A secure future, reputable work place, handsome remunerations determine the preferences of a medical graduate. For a medical student, being enrolled in a Post Graduate Programme is crucial and one of the toughest parts of his career. In our context, more than a thousand medical students graduate from inside and out of country every year. They have to compete against a narrow bottle neck to get into the handful medical institutes providing post graduate programmes with only very limited number of seats.

Post Graduation (PG) in medical field has two options: one is to pursue a career in the pure clinical field and the other is to join allied/ basic science subjects. In comparison to the huge attraction towards the clinical subjects, basic science subjects have failed to be a promising trail among medical students.

\section{PRESENT SCENARIO}

A medical student in Nepal after graduation has very limited options for both clinical and allied subjects. ${ }^{1}$ Post Graduation degree has become mandatory to start a permanent career. The current scenario has two possibilities for sites of PG training, either in centres inside the country, or outside. Within Nepal, Institute of Medicine, B.P. Koirala Institute of Health Sciences, National Academy of Medical Sciences and a few medical colleges affiliated to Kathmandu University are the major centres providing PG programs; however, the seats are very limited in number. ${ }^{2}$ There is a huge discrepancy between the number of students graduating from MBBS and the number of PG seats available. This has created a huge pool of medical graduates waiting to enrol in a PG program with new batches of freshly graduated medical students added to this pool every year.

Outside Nepal, students can try for medical colleges of our neighbouring nations; some opt for USMLE or PLAB tests in the western world. In both of these choices, the competition is at its highest level ever. Extreme dedication, which might cost a toll of good number of working years, is mandatory for these options. 


\section{HINDRANCES}

Embarking on a basic science career is considered as a failure, a dumping site for the weak, and outcasts who leak outside the norm. Non-clinical fields, allied subjects are not and have never been an "alternative" for PG courses. Very low inclination of medical students towards basic science course can be seen by the small number of applicants for these subjects. Students who have failed trying their luck elsewhere stumble upon basic science careers. It can also be further verified by the fact that students do not need to go through the most dreaded written tests, unlike other clinical choices and can directly sit for an interview if they are interested in basic science course in some universities of our country. ${ }^{3}$

Medical education in Nepal is an expensive field of study. ${ }^{4}$ Self financed seats are very expensive that they are beyond reach of a common Nepali citizen. This huge expenditure adds up the pressure on students to lead a career path in clinical science which appears to be more promising economically.

Adding to it is the fact that a medical student has very less idea of life beyond internship. Majority of the students are unaware of the alternatives besides clinical medicine that are available after graduation. During preclinical courses, students too often perceive biomedical sciences as not being "relevant" to clinical care. ${ }^{5,6}$ This in part reflects the failure to curricula to devote adequate time and effort to impart upon students a true understanding of the science and link it to a sophisticated approach to thinking in the clinical setting.

Studies show that a good mentorship is the most determinable factor in career choice of a medical student. ${ }^{7}$ There is a huge inadequacy of teachers who teach basic sciences in our country. ${ }^{8}$ Compulsory requirement of one clinical faculty for seven others in each department is not met in most of the medical colleges. ${ }^{9}$ This deficiency is compensated by hiring foreign faculties. Majority of the lecturers and professors are from neighbouring nations, who have ended up their careers in their country. ${ }^{8}$ A good mentorship able to influence the young minds can hardly be expected from them.

\section{WAY FORWARD}

The progress of science, human medicine is based upon researches made by the basic researchers. Basic scientists are the pillars of academe upon whom the power of generation of medical manpower is bestowed. This branching should be seen as a valuable opportunity for spreading science into a broader horizon. Career planning and professional skills development should be done meticulously to ensure the success of basic scientists as they contribute, in a variety of related career paths, to a broadly defined global medical enterprise. Further, studies have shown that basic science knowledge is an asset to clinical decision making. Knowledge of basic science is always important to confront with critical clinical scenario. Analysing the disease scenario with the necessary pathophysiology, biochemistry, anatomy leads to a better management and integration of relevant basic science mechanisms to the teaching of disease which has the potential to improve retention and diagnostic application of the information in the students. ${ }^{10-12}$

There is a need to glamorize basic science education. Joining basic science as a result of compulsion is not productive. Students should be made aware of the opportunities that lie ahead in this field. Better perception of biomedical science and its role for improving health care are powerful motivators in inspiring medical students to pursue research careers. Exposure to role models during training, both physician-scientists and physician-educators, who illustrate the integration of science and clinical practice are important for motivating the students. ${ }^{13}$

There should be an understanding that basic medicine has more to it than just giving lectures and doing lab works. There is a dire need of young energetic aspirants joining this field of specialization in medicine, who are ready to explore the unexplored and be the ideal role model for other students to come.

\section{CONCLUSION}

To conclude, career is not always promising in basic sciences especially in a nation like ours, where research, career building opportunities are very limited; this area is not exempt to this shortcoming. For me and for now like an American poet Robert Frost writes: "Two roads diverged in a wood and I took the one less travelled by."

\section{REFERENCES}

1. Lamichhane J. Dilemma of medical graduates in Nepal. J Nepal Health Res Counc 2010 Oct;8(2):116-9.

2. KUSMS [Internet]. 2011 [cited 2013 Feb 28]. Available from: http:// www.dhulikhelhospital.org/index.php/academics/kusms.

3. Application for Postgraduate MD/MS Programs (Academic Year: 2013) [Internet]. 2011 [updated 2013 Feb 25; cited 2013 Feb 28]. Available from: http://dhulikhelhospital.org/index.php/component/content/ article/5-news-and-events/192-application-for-postgraduate-mdmsprograms-academic-year2013.

4. Huntington I, Shrestha S, Reich NG, Hagopian A. Career intentions of medical students in the setting of Nepal's rapidly expanding private medical education system. Health Policy Plan 2012 Aug;27(5):417-28.

5. West M, Mennin SP, Kaufman A, Galey W. Medical students' attitudes toward basic sciences: influence of a primary care curriculum. Med Educ 1982 Jul;16(4):188-91.

6. Custers EJ, Ten Cate OT. Medical clerks' attitudes towards the basic sciences: a longitudinal and a cross-sectional comparison between students in a conventional and an innovative curriculum. Med Teach 2007 Oct;29(8):772-7. 
7. Yap C, Rosen S, Sinclair AM, Pearce I. What Undergraduate Factors Influence Medical Students When Making Their Choice of Post Graduate Career? British Journal of Medical and Surgical Urology 2012;5(1):11-5.

8. Karki DB, Dixit H. An overview of undergraduate and postgraduate medical education in Nepal and elsewhere. Kathmandu Univ Med J (KUMJ) 2004 Jan-Mar;2(1):69-74.

9. Nepal Medical Council (NP). Accreditation Standards for the MBBS (Bachelor of Medicine and Bachelor of Surgery) Degree Program for Institutions Admitting 100 students Annually [Internet]. 2013 [updated 2011 Jun 17; cited 2013 Feb 28]. Available from: http:// www.nmc.org.np/downloads/93294.pdf.
10. Woods NN, Brooks LR, Norman GR. The role of biomedical knowledge in diagnosis of difficult clinical cases. Adv Health Sci Educ Theory Pract 2007 Nov;12(4):417-26.

11. Woods NN, Brooks LR, Norman GR. It all make sense: biomedical knowledge, causal connections and memory in the novice diagnostician. Adv Health Sci Educ Theory Pract 2007 Nov;12(4):40515.

12. Woods NN, Neville AJ, Levinson AJ, Howey EH, Oczkowski WJ, Norman GR. The value of basic science in clinical diagnosis. Acad Med 2006 Oct;81(10 Suppl):S124-7.

13. Sung NS, Crowley WF Jr, Genel M, Salber P, Sandy L, Sherwood LM, et al. Central challenges facing the national clinical research enterprise. JAMA 2003 Mar 12;289(10):1278-87. 